\section{Om kutting og bedring: å våge å tro på egne krefter}

Ved Kristin Ribe
Gud trøyste deg då,

du Veslemøy;

det vøre deg betre du måtte døy, så fingje $d u$ fred $i$ jordi.

(fra Arne Garborg: Haugtussa)

Jeg har sydd 2891 sting. Jeg har tatt flere titalls overdoser. Jeg har, i lange perioder av mitt liv, vært svært, svært i tvil om jeg vil leve. Nærmet meg døden, på mange måter. Og likevel er jeg her nå. Som forfatter, noen ganger som foredragsholder, som venninne, i relasjoner der jeg både kan gi og få og føle. Jeg har ikke tatt livet mitt. Men ja, det har vært en lang lang vei. Noen uttalelser om meg, underveis: "Meget alvorlig skade." "Nær ved å miste livet." "Å regne som dødssyk de siste 6-7 årene.” "En dyptgripende eksistensiell krise." "Du har brukt mange av dine 9 liv nå.” Og psykologen sa til meg: "Ja. Du er i stand til å ta livet av deg."

\section{Det farlige livet}

Som en gang etter en overdose, det å ligge på overvåkningen og spy og spy og spy, kjenne smertene i magen, ligge der og love meg selv at de tablettene, de tar du aldri aldri mer, og så, etter et år, likevel gjøre det en gang til. Eller en annen overdose, der jeg kunne lese i epikrisen etterpå at jeg var fullstendig bevisstløs, uten smertereaksjon ved innkomst, og med "svekket respirasjon, angivelig fått svelgtube og ventilatorisk assistanse fra anestesi," med "multiple sår på armer og buk" og jeg tenker: Ja, det er alvorlig. Jeg er virkelig ikke sikker på om jeg vil leve. Men mye av kuttinga var det motsatte: for å kunne holde ut enda litt til, ikke ta enda en sånn dose.

Og likevel. Det står så ofte, og mange mener, sier til meg: "Selvskading er aldri for å d $\varnothing$, men bare for å skade, lage et sår." Det kan være sånn. Men det er også så mye mer. Fra en slik rein skade for å holde ut livet og smerten - og: til det å direkte kjenne etter hvor pulsåra banker og kutte seg der, men også, og det er i seg selv ganske farlig, det å være likegyldig til utfallet, villig til å ta sjansen på hva som helst som måtte komme. Men kutting er også, som jeg sa: $\AA$ holde selvmordet på avstand. Ja, jeg blør, men akkurat det gjør at jeg kan holde ut alt dette vonde litt til. Og når det gjelder stingene, det å telle stingene, kom nok det mye av at de ikke bare var destruktive tegn for meg, men også vitne om helbredelse, et tegn på at jeg holdt på å gro bittelitt mer sammen, inni. Og enda viktigere, at noen ville hjelpe, og hadde gjort en innsats for å få meg bittelitt helere.

\section{Min lengsel i smerten:}

\section{Så fingje du fred i jordi}

Hvis jeg d $\varnothing$ de, ville jeg slippe mye vondt. De rundt ville kanskje ikke, i den første tida, forstått noen ting og det ville, tror

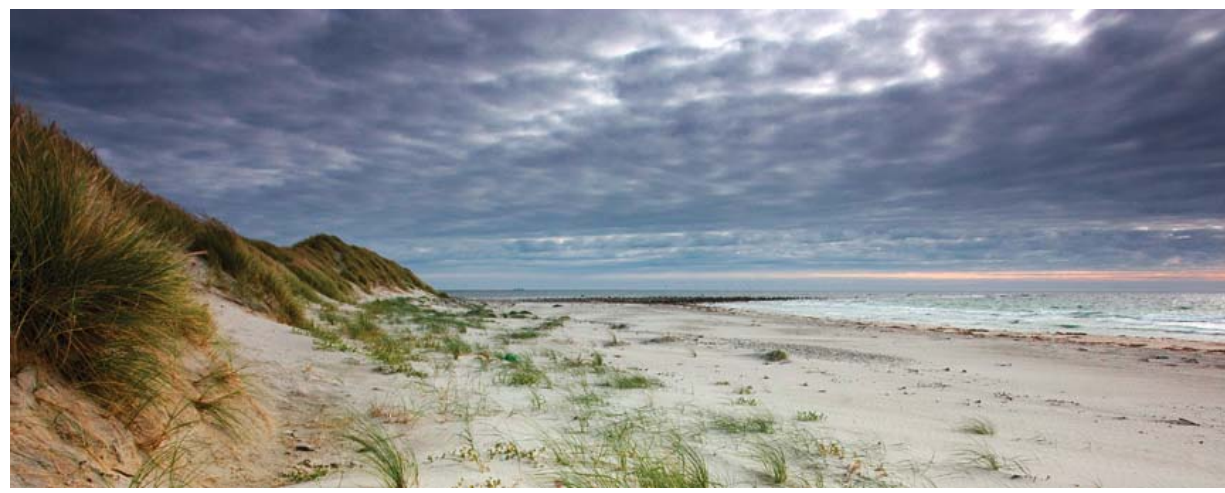

jeg, den gangen ha vært en "plutselig død", en "uforklarlig død", ingen visste hvor lei meg jeg var. Men så ble jeg innlagt. Og jeg fikk en ny psykolog som ikke ga seg med det trygge, en psykolog jeg var kjemperedd og sint på - men som virkelig også viste meg både interesse og medfølelse. Så jeg bestemte meg for å utsette selvmordet, ta sjansen, gi det et år, se, om det kunne bli bedre. Men trøsten jeg fikk og innsiktene jeg fikk i det vonde, gjorde jo alt mye vanskeligere. Da gjorde alt virkelig vondt, da virkelig ville jeg dø. Det å oppleve en god relasjon ble både triggende og styrkende på samme tid, triggende: fordi det tydeliggjorde så veldig hva jeg ikke hadde fătt før, men også styrkende: fordi jeg var i et annet menneskes tanker.

\section{Håpløst tilfelle?}

Men på tross av god hjelp: Jeg ville gjerne slippe. Jeg ville gjerne d $\varnothing$, få en god himmel. Men jeg var også utrolig redd for at jeg var et håpløst tilfelle etter hvert som selvskadingen utartet, ble mer og mer voldsom. Psykologen min sa - i ettertid - at det å måtte sy hundre sting på en gang er så alvorlig og så omfattende, at det nesten kan lignes med langt framskreden kreft: For hva skal man ta tak i? Hvordan gripe an et så skada menneske? Men han trodde på meg. Vi jobba sammen i ti samfulle år. Og etter hvert kunne han si til meg: "Du er jo kommet så langt. Du kan da ikke gi opp nå." Men; som Lars Mehlum (1999) skriver: "I psykiatrien må vi også innse at en del pasienter er uhelbredelig syke og er gått i stykker så grundig at de ikke kan leges med de behandlingsmetoder vi rår over i dag." - en setning som bekreftet mine vondeste anelser.

\section{Den lange veien}

Men de på Østmarka psykiatriske sykehus sa også, tydelig, til meg: "Sånne ting som du sliter med tar tid. Vi tror på deg. Du er ikke et håpløst tilfelle. Hadde du vært det, hadde vi brukt tida på noen andre." Men likevel: De skreiv meg ut. Om igjen og om igjen til utryggheten. Og jeg skjønte ikke hvorfor, når jeg var så kolossalt lei meg, skjønte ikke at det de fors $\varnothing$ kte å lære meg var at jeg måtte kunne tørre å be om hjelp, og jeg måtte lære å kjenne etter: Hva trenger jeg akkurat i dag? Det dumme i dette, i starten, var selvfølgelig at jeg, når de hele tida skreiv meg ut mot min vilje, ikke trodde de ville hjelpe. Og sånn ble tvangsinnleggelser det eneste igjen å gjøre etter andre og tredje gangs sying på samme dag. Men viktig: Jeg ville, innerst inne et sted ville jeg svært gjerne ha hjelp. Jeg var bare gått så i vranglås. Og derfor var jeg på mange vis også glad for tvangsinnleggelsene, fordi jeg, når jeg sa nei til innleggelse, trengte noen 


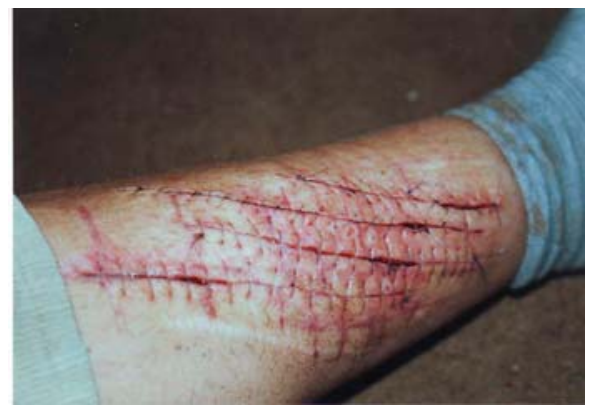

utenfor meg som ville at jeg skulle leve og ville at jeg ikke skulle skade meg sjøl sånn. At jeg skulle være verdt noe som menneske. Jeg måtte gå den lange tunge veien og se, langsomt erfare at det, når det virkelig stormet, var mulig å få trøst - ikke blodets trøst, men samtalens trøst.

\section{Is i magen}

Selvmordsfors $\varnothing \mathrm{k}$ er if $\varnothing$ lge Nils Retterst $\varnothing \mathrm{l}$ (1995) "en av de viktigste risikofaktorer for senere selvmord, da så mye som over 10 prosent av denne gruppen pasienter senere dør på en slik måte, et tall som er enda høyere for de med langvarig suicidal karriere.” Jeg la dette fram for psykologen min. Jeg var redd. Jeg har en langvarig suicidal karriere, jeg var redd for å d $\varnothing$ uten å ville det helt. Og han sa: "Men det er 90 prosent som klarer seg" - en helt annen måte å se det på. Og her må noe sies om å ha is i magen. Jeg forstår at det er tøft å stå i dette for behandlerne. Men: Jeg må selv kunne si i fra, jeg må, MA lære meg å be om hjelp, jeg kan ikke basere livet mitt på andres mer eller mindre gode gjetninger.

Psykologen sa en gang: "Det er leit å forlate deg sånn, når du er så lei deg.” Men han stolte på meg. Han sa at nå er timen slutt og satte en grense, men også: Han stolte på meg at om det blei for ille så kunne jeg greie å søke hjelp. Eller mange ganger greide jeg det ikke, men det var en ting jeg måtte lære. Han kunne ikke være der for meg hele tida, resten av livet, ingen kan det. Jeg må lære meg til å se at jeg er verdifull nok til å få hjelp, til å få av andres velvilje og tid. Jeg må lære meg at egne krefter faktisk er nok til å stå imot kuttetrang, at jeg har krefter nok til å komme meg i sikkerhet - og noen som vil at jeg skal gjøre det. Men det er vanskelig.

\section{Åpen retur}

Etter ca. tre år fikk jeg åpen retur ved sykehuset. Når jeg var så altfor sliten av å prøve meg i livet, var veien til neste kutt eller overdose dessverre så kort. Jeg ble bare plutselig så overvelda av sinne og av sorg. Men de krevde samtidig omtrent det umulige av meg: At jeg skulle kjenne på behovet, kjenne at det ikke er like stort hele tida, og om det var for vondt å være meg: Be om hjelp. Og, som jeg omtrent fikk hakeslipp av: De forventet at jeg ikke bare skulle gjemme meg unna ønsket om å d $\varnothing$, være innelåst og fratatt ansvar, de spurte, fra første innleggelse: "Hva har du tenkt å bruke innleggelsen til?" Et spørsmål så forbausende at jeg bare sa: "Jeg begynner ikke å strikke, hvis det er det dere tror," noe som jo selvfølgelig ikke var akkurat det de tenkte på. I den desidert vanskeligste perioden i mitt liv ble jeg på denne måten tvunget til å se framover. Hva ønsker jeg av andre mennesker, hva vil jeg at mitt liv skal inneholde? Og det var, som jeg nå ser det, ganske fint, ganske lurt. Sykehuset skulle ikke være en oppbevaringsplass, men et sted å hente inn krefter, trene på relasjoner. I de første innleggelsene var jeg bare "Hun mørke som ikke sier noe." Jeg gikk mye og gjemte meg, under sofaer, inni og oppå skap. Men personalet lot meg ikke være gjemt og glemt, de kom, kom og fant meg, ba meg bli med, på stua, til en samtale, de lot meg ikke, indirekte eller billedlig, være $\mathrm{d} \varnothing \mathrm{d}$, være borte. De ville ha meg hos seg. De ville ha meg levende.

\section{Det vanskeligste av alt: det å føle verdi}

Jeg hadde åpen retur. Og visste jeg bare kunne komme. Men, det er vanskelig å føle verdi, føle at man er verdt at andre skal kunne, ville bruke tid på meg, nå.

Og, det er ganske vanskelig å spørre om hjelp når man nettopp har fått høre at det beste er om du ikke er hos oss, vi kan ikke ha deg her hele tida. Det ble mange runder, og alvorlige runder før jeg skjønte mer av det. Så jeg kutta. Jeg tok overdoser, hoppa i sjøen, var i fare for å dø mens noen fortalte meg gang på gang på gang: "Det er ditt valg, vi kan ikke hindre deg hvis du virkelig vil," en setning som har vært vond, virkelig VOND å høre. For meg virket dette ikke

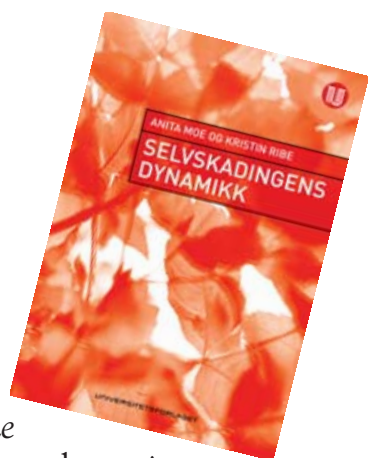

som det muligens er tenkt, at jeg

skal ta mer ansvar. For meg betydde det i stedet, "Ta nå det valget, da, det er helt greit for oss om du dør, bare gjør det. Det er denne fomlingen vi ikke liker, gjør det skikkelig." Noe som fikk meg gang på gang til å tippe forferdelig over.

Men jeg har vært ekstremt heldig. Det har vært noen som har sett, som har oppdaga, som har sendt meg på tvang, og, som til slutt sa, da jeg konfronterte dem med denne tilsynelatende likegyldigheten: "Herregud, jente, det er ikke greit at du dør". Eller som en sykepleier så utrolig bra sa det: "Det beste er om du ikke trenger oss, det verste er hvis du kutter deg." Når dette endelig ble formidla sammen, var det lettere å skjønne. Mye mye lettere.

\section{Både i pose og sekk?}

Veslem $\varnothing$ y hadde ei tung tid, tunge år foran seg. Ting Tar Tid. Særlig når det gjelder å få det bedre, å endre. Og i alt det vanvittig vonde tenkte jeg jeg kunne få hvile i jorda, i døden, hos gud. Jeg tror på en god $\mathrm{d} \varnothing \mathrm{d}$, på en himmel, i uendelig omsorg og trøst. Men jeg kan også ønske meg at det skal være mulig å få i både pose og sekk: Først et godt liv, så en god død. Gleden når noe er godt: "Herregud, dette vil jeg oppleve mer av." Og nå, ca 150 innleggelser senere, og, ikke minst, mange mange gode opplevelser senere: Jeg har ikke tatt livet mitt. Jeg lever.

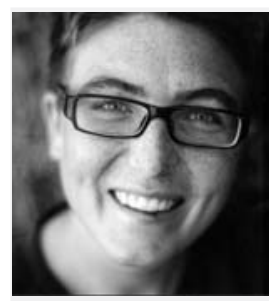

Kristin Ribe utga i 2007, basert på egne opplevelser fra over 13 år med alvorlig selvskading, fagboka Selvskadingens dynamikk, Universitetsforlaget, sammen med psykolog og stipendiat Anita Moe.

Det meste av materialet til denne artikkelen er hentet herfra. Hun har også utgitt romanene Forsnakkelser (2003), Drikke det vannet som ormene hadde ligget $i$ (2006) og VÅKE (Håret gråter jeg i) (2008), alle på forlaget Oktober. Hun har hovedfag i nordisk litteratur. www.kristinribe.no

kristin_ribe@hotmail.com

\section{Referanser}

Mehlum, L. (red.). (1999). Tilbake til livet. Kristiansand: Høyskoleforlaget.

Retterst $\varnothing 1$, N. (1995). Selvmord. Oslo: Universitetsforlaget. 